\title{
舌下腺にみられた腺癌例
}

\author{
渡邊 昭仁 ${ }^{1)}$ ・野平久仁彦 ${ }^{2)}$ ・畔田 貢 ${ }^{3)}$ \\ 由良 晋也 ${ }^{3)}$ ・白戸 勝 ${ }^{4)}$. 金井 直樹4)
}

\section{Adenocarcinoma of Sublingual Salivary Gland; A Case Report}

\author{
Akihito Watanabe, Kunihiko Nohira, \\ Mitsugu Kuroda and Shinya Yura \\ (Nikko Memorial Hospital) \\ Masaru Shirato and Naoki Kanai \\ (Asahikawa Medical School)
}

\begin{abstract}
A 40-year-old woman complained of a painless mass in the left side of the floor of the mouth. A $2 \times 2 \mathrm{~cm}$ round, smooth, nontender mass was palpable on the left side of the floor of the mouth; it was fixed to the symphysis of the mandible. No cervical lymph nodes were palpable. T2-weighted MRI scan of the tumor showed smooth margins and a heterogeneous signal. A contrast-enhanced CT scan showed a slightly enhanced mass lesion. Radionuclide scanning with ${ }^{67} \mathrm{Ga}$ showed a hot tumor. Radiography revealed a malignant tumor originating in a minor salivary gland or a sublingual gland. Microscopic examination of the tumor showed adenocarcinoma.

Radical neck dissection was combined with resection of the left side of the floor of the mouth and of the internal margin of the mandible. The surgical defect was reconstructed with a rectus abdominis musculocutaneous flap.

Postoperative evaluation of mastication and articulation was good. The patient had no evidence of recurrence one year after surgery.
\end{abstract}

Key words : sublingual gland salivary tumor, adenocarcinoma, reconstructive surgery, rectus abdominis musculocutaneous flap

はじめに

大唾液腺腫瘍は耳下腺，顎下腺に多く見られ， 舌下腺にみられることは比較的稀である。しか し，組織学的には耳下腺・顎下腺に比較して， 悪性腫瘍の占める割合が多く見られると報告さ れている，今回われわれは左舌下腺に由来した
腺癌症例を経験したので若干の文献的考察を加 え報告する。

症例

症例：41歳，女性.

主訴：口腔底の腫瘤.

現病歴：約 7 年前に口腔底の腫瘤にて近医を
1）日鋼記念病院耳鼻咽喉科

3）日鋼記念病院口腔外科
2）日鋼記念病院形成外科

4) 旭川医科大学耳鼻咽喉科学教室 
受診するも唾石症の診断にて放置されていた その後とくに症状なく経過していたが約 2 年位 前より徐々に増大傾向を示し，平成元年 8 月当 科を受診した。乙れまで自発痛，压痛等を自覚 したことはなかった。

既往歴：特記すべきことはなし.

家族歴：特記すべきととはなし.

初診時所見：口腔底左側に約 $2 \times 2 \mathrm{~cm}$ の硬い 腫瘤を触れた（図 1 )。腫瘤は左顎下腺前方に位 置し，境界は比較的明瞭であったが，可動性不 良であり下顎骨との癒着を認めた。左ワルトン 管からの唾液分泌は不良であった。頸部リンパ 節転移は認めなかった。

\section{検查結果}

左顎下腺造影検査：ワルトン管は拡張してお り，ワルトン管開口部での腫瘍による圧排で唾 液分泌障害がおきていると思われた。腫痬によ

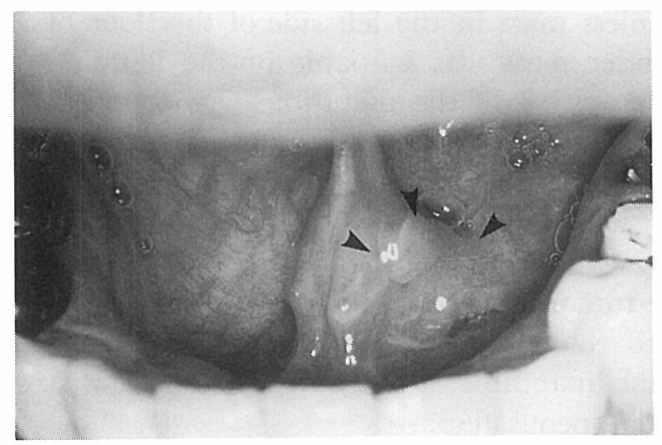

図 1 術前の口腔底部 矢印の部位に腫瘤が存在した。

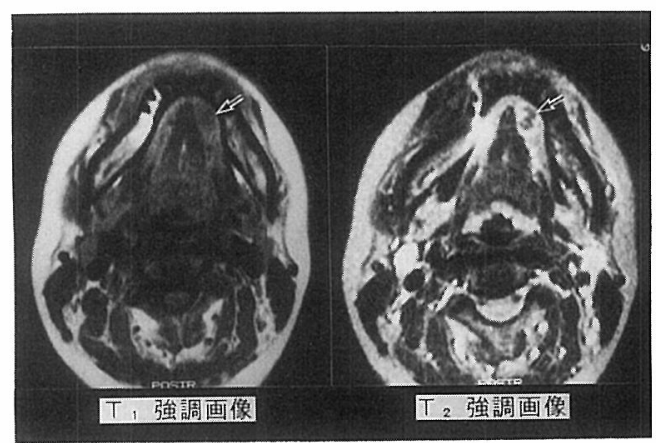

図 2 MRI 所見 矢印は腫瘍部分を示す。
る浸潤像等は認められなかった。

$\mathrm{CT}$ 検查：シアロ $\mathrm{CT}$ 検查で腫瘍は顎下腺と は離机前方に存在していた. enhanced $\mathrm{CT}$ 検査 では口腔底腫瘤は enhanceされ，下顎骨と接 していた，骨レベルにて骨への浸潤を疑わせる 所見はなかった。

MRI：T1 強調画像にて低信号の内部構造均 一，辺縁明暸な腫瘤が認められた. $\mathrm{T} 2$ 強調画像 では辺縁強信号, 内部構造不均一, 辺縁明瞭で あった(図2)。

超音波検査：腫瘍内部エコーは低エコーで均 一，辺縁エコーは一部不明暸な部分を認ぬた.

核医学検查： ${ }^{99 \mathrm{~m}} \mathrm{Tc}$ シンチグラムは明らかな 異常所見を認めなかった. ${ }^{67} \mathrm{Ga}$ シンチグラム にて腫瘍に一致して取り込みが方進していた。

以上より左舌下腺または小唾液腺由来の悪性 腫瘍を疑い，口腔底より生検した。病理結果は adenocarcinoma (tubular type) であった.

\section{治療}

平成元年 9 月手術的治療を行なった．左頸部 郭清術後，口腔底を形成する筋組織を含め, 腫 瘤と共に一塊に pull through 法にて摘出した. 口腔内切除範囲は右ワルトン管を外方に移動し, 右口腔底を一部含め, 左口腔底ほぼ全部と, 腫 瘍と接する下顎骨の内側皮質骨を含めた（図 $3,4)$. 次いで遊離腹直筋皮弁にてロ腔底の 再建を行なった。術後約 2 週間目より化学療法 $(\mathrm{CDDP}+5 \mathrm{FU})$ を 2 クール行い退院した。 術

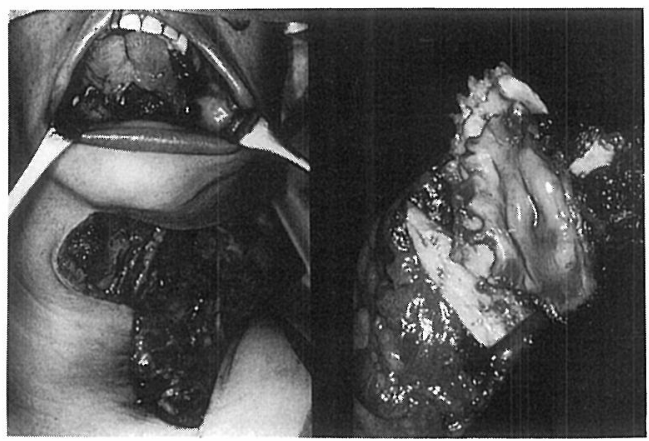

图 3 左は腫瘍摘出後, 右は摘出物を示す. 
後約 1 年になるが再発傾向なく, 現在外来経過 観察中である。

病理診断：ヘマトキリン・エオジン染色では 舌下腺中央に正常舌下腺之移行する well moderately differentiated adenocarcinoma がみら れた．腫瘍は大小不同の管腔をもち，周囲組織 とはよく境界されているが一部被膜に浸潤思 わせるところがみられた。鍍銀染色では上皮性 の配列をとり PAS 染色陰性，アルシアンブル 一染色陽性の酸性ムコ多糖類の粘液産生のある 腺癌であった(図 5 )。腫瘍は骨への浸潤は認め

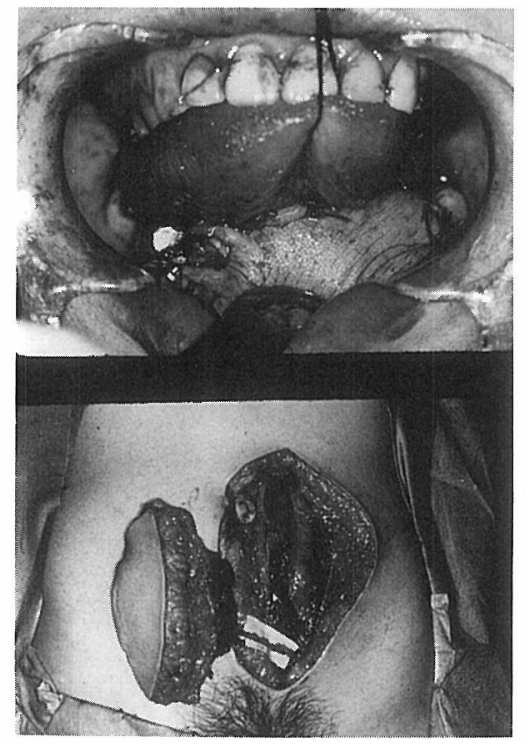

図 4 上段は皮弁再建後, 下段は腹直筋皮弁 採取時を示す。

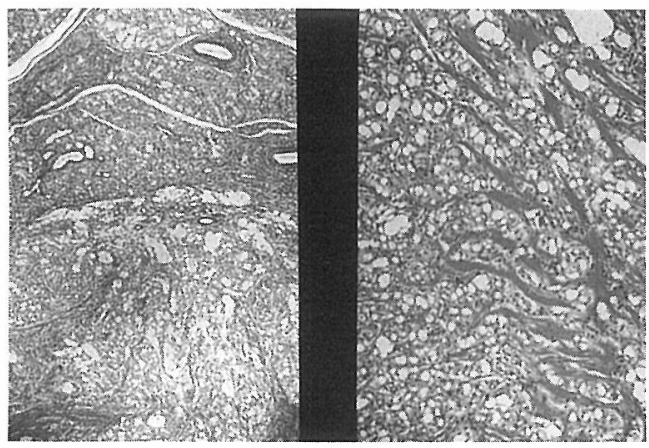

図 5 病理組織学所見

$\mathrm{HE}$ 染色, 左 $\times 20$, 右 $\times 100$
られなかったが，骨膜とは接して存在していた。 また摘出したリンパ節には転移はみられなかっ た.

\section{考 察}

大唾液腺腫瘍は多くは耳下腺，顎下腺に見ら れ，舌下腺に見られることは比較的稀とされ ている. Foote ら ${ }^{1)}$ は大唾液腺腫瘍877例中 4 例 （0.5\%）が舌下腺に見られたと述べ, Gore ら は64例中 3 例 (4.7\%) が舌下腺腫瘍であったと 報告している。本邦においても野崎ら ${ }^{3)} 108$ 例中耳下腺は87例，顎下腺は 20 例，舌下腺は 1 例 $(0.9 \%)$ のみ認められたと報告している。

舌下腺腫瘍は良性，覀性を比較すると悪性が 多くみられるとの報告が多く，Turnbull ら4) 耳下腺腫瘍において，34.19が悪性であり，顎 下腺腫瘍は $55.7 \%$ が悪性であり，舌下腺では $100 \%$ つまり全例が悪性であったと報告してい る. Rankowら ${ }^{5}$ は自験例15例は全例悪性であり 過去の文献とあわせても $80 \%$ が悪性であったと 報告している。乙れら舌下腺悪性腫瘍の病理組 織は腺様囊胞癌，粘表皮腫瘍が高頻度に見られ， 次いで，多形腺腫内癌，腺癌が見られる。腺癌 は舌下腺腫瘍の症例の中でも比較的稀であり， Nishijima ら ${ }^{6)}$ は過去の文献等にて検索した舌 下腺悪性腫瘍59例中 7 例のみが腺癌であったと 報告している. 舌下腺腫瘍は発生頻度的には比 較的稀ではあるが，悪性腫瘍のととが多く舌下 腺腫瘍を疑ったときは悪性の可能性が高いとと を念頭にいれて治療する必要があると思われる。

唾液腺腫瘍の治療方法は良性悪性を問わず手 術治療が中心となっている，悪性腫瘍について は特に初回の治療が大事であるとの報告が多 (415)7). 術前の生検については否定的な意見が 多いが，今回われわれは，舌下腺または小唾液 腺の悪性腫瘍を疑い，その組織型を確認するた めに予定手術の直前に生検を行なった，Rosenfeld $^{7}$ は悪性多形腺腫, 腺様襄胞癌は他の悪性 腫瘍よりは拡大摘出が必要と述べて抒り，術前 に組織を知るととは手術時の摘出範囲を考慮す るのに参考になると考えられる。無意味な生検 
術は予後を悪くする可能性があるが，治療過程 の一つとして行なう生検術は，十分に意味のあ るものと考える. 今回われわれは頸部郭清術を 行ない, pull through 法にてロ腔底から摘出し ている. このようにすることにより，十分な摘 出範囲を取ることができる，また，皮弁にて口 腔底を再建することにより十分な広がりをむっ た口腔底が作られ，残された舌の運動制限を最 小限におさえ構音的にあ大きな障害を残すこと なく，咀嚼運動むうまく行われている.

大唾液腺腫瘍の腺癌の予後は, 局所再発が33 \%にみられ，肺転移は $21 \% ， 5$ 年生存率は $54 \%$ ， 10 年生存率は $44 \%$ であると述べられている ${ }^{8}$. われわれの症例屯現時点では再発傾向はないも のの，今後の厳重な経過観察が必要であると考 えている.

\section{まとめ}

1. 舌下腺由来の腺癌症例を報告した.

2 . 予定手術前の生検は手術方法等を決める ために有意義であると思われた．

3. 口腔底を皮弁を用い再建するととで, 術 後の構音機能，咀嚼機能の障害を少なくできる と.思われた.

本論文の要旨は第52回耳鼻咽喉科臨床学会 (平成 2 年 7 月 13 日, 久留米) にて発表した.

\section{参考文献}

1) Foote FW and Frazell EL : Tumors of the major salivary glands. Cancer $6:$ 1065 1133, 1953.

2) Gore DO, Annamunthodo $H$ and Harland A : Tumors of the salivary gland origin. Surg Gynecol Obstet $119: 1290 \sim 1296,1964$.

3 ）野崎秋一, 三吉康郎, 坂倉康夫, 他 : 大唾液腺腫 瘍の臨床統計的観察. 耳鼻臨床 $74: 1044 \sim 1053$, 1981.

4) Turnbull AD and Frazell EL : Multiple tumors of the major salivary glands. Am J Surg 118 : 787 789, 1969.

5) Rankow RM and Mignogna F : Cancer of the sublingual salivary gland. Am J Surg 118: 790 ح95, 1969.

6) Nishijima W, Tokita N, Takooda S, et al : Adenocarcinoma of the sublingual gland. Laryngoscope $94:$ 96 101, 1984.

7 ) Rosenfeld L, Sessions DG, McSwain B, et al : Malignant tumors of salivary gland origin. Ann Surg $163:$ 726 735, 1966.

8) Shidnia H, Hornback NB, Hamaker R, et al : Carcinoma of major salivary glands. Cancer $15: 693 \sim 697,1980$.

原稿受付 : 平成 2 年 8 月 27 日 原稿採択 : 平成 2 年 10 月 5 日 別刷請求先 : 渡邊昭仁 T501 室蘭市新富町1-5-13 日鋼記念病院耳鼻咽喉科 